\section{Diversity and abundance of Avifauna of Manglot Wildlife Park, Nowshera District, Khyber Pakhtunkhwa, Pakistan}

\author{
Tariq Mahmood ${ }^{1 *}$, Luqman Ullah Khan $^{1}$ and Muhammad Naeem ${ }^{2}$ \\ ${ }^{1}$ Department of Wildlife Management, PMAS Arid Agriculture University Rawalpindi \\ 46300, Pakistan \\ ${ }^{2}$ Department of Entomology, PMAS Arid Agriculture University Rawalpindi 46300, \\ Pakistan
}

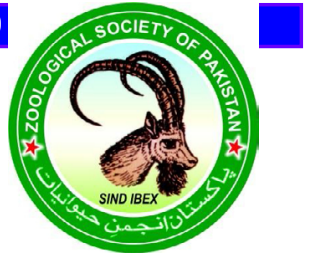

Article Information

Received 01 November 2019

Revised 03 February 2020

Accepted 20 February 2020

Available online 15 June 2021

Authors' Contribution

TM and LUK designed and planned the study. LUK collected the field data.

TM wrote the manuscript. FA and MN analyzed the data.

Key words

Avifauna, Abundance, Diversity,

Species richness, Manglot

\section{INTRODUCTION}

B inersity is the sign of a healthy ecosystem. Avian diversity is very important to attract people and tourists towards natural habitats. Bird distribution is particularly important being commonly used as indicator of ecological conditions (Schrage et al., 2009). Out of approximately 9040 species of birds around the world, about 2060 species occur in the Indo-Pak Subcontinent and it constitutes about 13 percent $(13 \%)$ of the total global bird population. Pakistan has more or less 660 bird species (Roberts, 1991), that reflects a greater diversity of habitats in the country and its important zoogeographic position (Pathan et al., 2014). Forty three percent (43\%) of birds in Pakistan are Palaearctic species; which visit Pakistan only during breeding seasons; and 30 percent visit during winter or summer season across the country.

Pakistan harbours a wide variety of avifauna because

\footnotetext{
* Corresponding author: tariqjanjua75@uaar.edu.pk 0030-9923/2021/0005-1623 \$9.00/0

Copyright 2021 Zoological Society of Pakistan
}

of its considerable diverse habitats. Birds annually migrate towards wetlands of Pakistan to manage harsh climatic conditions in northern latitudes. Worldwide, birds use seven fly routes; Flyway 4, Indus Flyway passes through Pakistan (Ali, 2006).

Birds perform some important services, especially in agro-ecosystems; many insectivorous bird species act as biological control agents by consuming harmful insects of crops. Some bird species also help in pollination of plants (Klein et al., 2007). The seed eating birds are also involved in the dispersal of plant seeds. Raptors keep a check on rodent populations while scavengers eliminate the dead animals and thus help in environmental sanitation of agroecosystems (Whelan et al., 2008).

The avifauna of Khyber Pakhtunkhwa (KP) province is very diverse but likely to be declining due to ground hunting, poaching and trapping of various bird species, especially the migratory bird species. The Wildlife Department of the province has declared some areas as Protected Areas (National Parks, Wildlife Sanctuaries and Game Reserves) (Pathan et al., 2014) to conserve biodiversity and to provide a way for measuring the 
progress of such conservation. Some areas have further been established to help breed rare and threatened species such as Crane Conservation Centre, Lakki Marwat, and Thanedarwala (Dera Ismail Khan), KP for the conservation of migratory cranes and waterfowl, respectively (Shah, 2011). Some natural wooded areas that provide habitat for a wide variety of wild animals and birds have also been developed to serve as conservation and recreational areas like Manglot Wildlife Park, located in District Nowshera, KP. The Park is an important area for harbouring the diversity of avifauna, however, data on occurrence of bird species in the Park are lacking. The study was started to document the diversity of bird species occurring in Manglot Wildlife Park and to estimate their abundance.

\section{MATERIALS AND METHODS}

\section{Study area}

The study was conducted at Manglot Wildlife Park (71 ${ }^{\circ} 56^{\prime} 37.453^{\prime \prime}$ to $72^{\circ} 1^{\prime} 18.854^{\prime \prime} \mathrm{E}$ and $33^{\circ} 45^{\prime} 7.181^{\prime \prime}$ to $\left.33^{\circ} 47^{\prime} 15.036^{\prime \prime} \mathrm{N}\right)$ covering an area of 1759 hectares with the elevation ranging from $328 \mathrm{~m}$ to $504 \mathrm{~m}$ (Fig. 1). Manglot Reserved Forest has been declared a Wildlife Sanctuary since 1977 under section 15 of the Khyber Pakhtunkhwa Wildlife Act, 1975. Subsequently it was given the status of a Wildlife Park in the year 1992 to be managed as destination for ecotourism, recreation and for running awareness campaigns.

Plains dominate the topography of the park with some mountains and low hills up to $1000 \mathrm{~m}$ elevation above mean sea level. Scrub forest is the main vegetation type in the Park. The dominant plant species here include Zizyphus nummularia, Reptonia buxifolia, Tecoma undulate, Acacia nilotica, Dodonaea viscosa, Monothica buxifolia. Olea ferruginea, Tylophora hirsute, Ficus bengalensis, Calotropis procera, Grewia oppositifolia, Rhazya stricta, Prosopis juliflora, Capparis aphylla. The dominated grasses like Cynodon dactylon, Eleusine compressa, Cymbopogon jwarancusa and Aristida adscensionis (Khyber Pakhtunkhwa Wildlife Department, 2015).Average annual temperature is $18.4^{\circ} \mathrm{C}$, which varies during the year by $23.5^{\circ} \mathrm{C}$, while the average rainfall is 532 mm (Khyber Pakhtunkhwa Wildlife Department, 2015).

\section{Methodology}

The study was conducted from September 2017 to July 2018. Reconnaissance survey was undertaken to select sampling sites to record data on bird diversity and abundance. Four sampling sites including Wildlife Range Office (Site-I), Wildlife Rest House (Site-II), Karkareena Top (Site-III), and Compartment No. 3 (Site-IV) were selected depending upon their potential for harboring bird species. The selected sites were visited on fortnightly basis to collect data using "Point Count Method" following Bibby et al. (2000). Data were collected in the morning (6:30 am to 9:30 am) and in the evening (3:30 pm to $6: 30 \mathrm{pm})$.

The bird species were field observed, using the binoculars (10x $50 \mathrm{~mm}$ ) and Zoom-scope (15- 60 x 60 $\mathrm{mm}$ ) and identified using field guides by Ali and Ripley (1987), and Grimmett et al. (2008). The field photographs of bird species sighted were taken using a digital camera. Geographical coordinates of locations were recorded using a Global Positioning System (GPS) device (Garmin eTraxVista). In addition, nests of different bird species were observed as an evidence of their occurrence and breeding in the study area.

The vantage points were selected having fixed radius of $200 \mathrm{~m}^{2}$, while the time duration for each point was fixed as 15 minutes. Calls of different bird species were listened, and recognized at each of the four selected sampling sites. The data recorded were analyzed using the following formula to compute the abundance of different bird species;

$$
\mathrm{Pi}(\text { Relative abundance })=\mathrm{ni} / \mathrm{N}
$$

Where $\mathrm{Pi}=$ relative abundance of species, $\mathrm{i}=1$, ni= number of individuals of species, $\mathrm{N}=$ total number of individuals of all species.

In addition, "Shannon diversity index" was used to estimate bird diversity using the formula;

$$
\mathrm{H}^{\prime}=-\sum\left(\mathrm{Pi}{ }^{*} \ln * \mathrm{Pi}\right)
$$

Where $\mathrm{H}^{\prime}=$ Shannon diversity index, $\mathrm{Pi}=$ Relative abundance, $\ln =$ Log with base "e" (natural logarithm).

Similarly, Evenness Index (E) was calculated using the formula;

$$
\mathrm{E}=\mathrm{H}^{\prime} / \mathrm{Ln} \mathrm{S}
$$

Where, $\mathrm{H}^{\prime}=$ Shannon diversity index, $\mathrm{S}=$ Total number of species, Ln= Log with base "e" (natural logarithm).

\section{RESULTS}

\section{Avian diversity}

A total of 51 bird species belonging to 10 orders and 27 families were recorded in the Manglot Wildlife Park, during the current study, including both summer and winter visitors.

\section{Order passeriformes}

The Passeriformes was the most abundant order having 16 families and 33 species occurring in the park (Table I). All Passerine species occurring in the area have been categorized as "least concern" (LC) as per IUCN red list of threatened species 2019-2. The common bird species in this order included house crow, tree pie, indian myna, black drongo, white-cheeked bulbul, red-vented 
bulbul, white wagtail, jungle babbler, common babbler, crested lark, house sparrow, common rose finch and Eurasian golden oriole. Most of these Passeriformes feed on insects and control their populations, and also feed on plant seeds playing important role in seed dispersal of plants.

\section{Order Galliformes}

The order Galliformes was represented by only one family Phasianidae represented by four species viz., grey francolin, black francolin, chukor partridge, and see-see partridge (Table I).

\section{Order Columbiformes}

This order was represented by only one family Columbidae which included two species occurring in the park, that is the laughing dove and Eurasian collared dove (Table I).

\section{Order Falconiformes}

This order was represented by two families viz., Accipitridae and Falconidae. The Accipitridae included white-rumped vulture, shikra, tawny eagle and shorttoed snake eagle whereas the family falconidae included only one species, the common kestrel.

The critically endangered white-rumped vulture was sighted at only two sites (site-II and III) where six individuals were recorded. Similarly, only two individuals of the tawny eagle were sighted at only one site (site-II), common kestrel was sighted at two sites (site-III and IV) represented by only three individuals. Short-toed snake eagle was recorded at three sites with only one individual being sighted at each site (Table I).

\section{Avian abundance}

Avian abundance was computed at four selected sites (Table I) as detailed below:

\section{Site-I (Wildlife Range office)}

At sampling site-I, 35 bird species were recorded, the most abundant being the tree pie with relative abundance $(8.73 \%)$, followed by black drongo $(8.73 \%)$, house crow $(6.34 \%)$, common babbler $(5.56 \%)$, house sparrow $(4.76 \%)$, sykes nightjar $(4.76 \%)$, purple sun bird $(3.97 \%)$, Eurasian tree sparrow $(3.96 \%)$, baybacked shrike and long-tailed shrike (3.18\%), striated babbler $(2.38 \%)$, jungle babbler $(2.38 \%)$, paddy field pipit $(1.58 \%)$ and white wagtail $(0.79 \%)$ (Table I).

\section{Site-II (Wildlife Rest House)}

Thirty Six (36) bird species were recorded at this site during the study (Table I); the most abundant was crested lark with relative abundance of $(6.96 \%)$, followed by Eurasian collard dove (6.95\%), house crow (6.09\%), red-vented bulbul (6.08\%), pied bush chat (6.08\%), Indian silver bill (4.35\%), and laughing dove (4.35\%) (Table I).

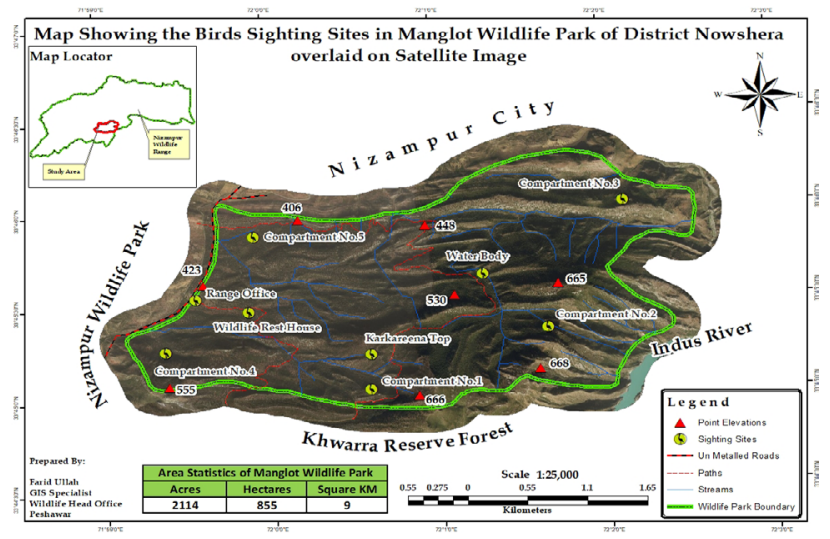

Fig. 1. Map showing location of Manglot Wildlife Park, Nowshera district, Khyber Pakhtunkhwa province and sampling sites in the park.

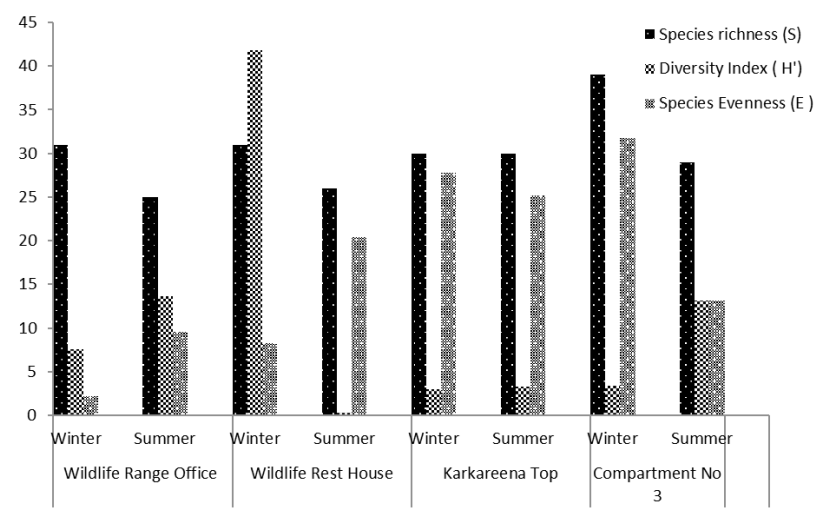

Fig. 2. Bar chart showing variation in population indices (species richness, diversity index and species evenness) of the avifauna at Manglot Wildlife Park, Nowshera, Khyber Pakhtunkhwa province during summer and winter seasons.

\section{Site-III (Karkareena top)}

At sampling site-III, a total of 37 bird species were found. The most abundant species was house crow with relative abundance $(7.32 \%)$, followed by common babbler (6.50\%), house sparrow $(5.69 \%)$, red-vented bulbul and purple sun bird (4.88\%), black francolin (4.87\%), and tree pie and Sindh sparrow (4.07\%) (Table I). 
Table I. A check list of diversity and abundance of Avifauna recorded at Manglot Wildlife Park, Nowshera District, Khyber Pakhtunkhwa province during September 2017 to July2018. *A, Abundance;*RA, Relative Abundance.

\begin{tabular}{|c|c|c|c|c|c|c|c|c|c|c|c|}
\hline \multirow[t]{2}{*}{ S.No. } & \multirow[t]{2}{*}{ English / Local name } & \multirow[t]{2}{*}{ Scientific name } & \multicolumn{2}{|c|}{ Site-I } & \multicolumn{2}{|c|}{ Site-II } & \multicolumn{2}{|c|}{ Site-III } & \multicolumn{2}{|c|}{ Site-IV } & \multirow{2}{*}{$\begin{array}{l}\text { IUCN } \\
\text { status }\end{array}$} \\
\hline & & & $\mathbf{A}$ & $\mathbf{R A}$ & $\mathbf{A}$ & RA & $\mathbf{A}$ & $\mathbf{R A}$ & $\mathbf{A}$ & $\mathbf{R A}$ & \\
\hline \multicolumn{12}{|c|}{ Order: Passeriformes } \\
\hline \multicolumn{12}{|c|}{ Family Laniidae } \\
\hline 1 & Bay backed shrike & Lanius vittatus & 4 & 3.17 & 2 & 1.73 & 0 & 0 & 2 & 0.84 & $\mathrm{LC}$ \\
\hline 2 & Long tailed shrike & Lanius schach & 4 & 3.17 & 2 & 1.73 & 1 & 0.81 & 5 & 2.11 & $\mathrm{LC}$ \\
\hline \multicolumn{12}{|c|}{ Family Corvidae } \\
\hline 3 & Tree pie & Dendrocitta vagabunda & 11 & 8.73 & 3 & 2.60 & 5 & 4.06 & 16 & 6.77 & $\mathrm{LC}$ \\
\hline 4 & House crow & Corvus splendens & 8 & 6.34 & 7 & 6.08 & 9 & 7.31 & 8 & 3.38 & $\mathrm{LC}$ \\
\hline \multicolumn{12}{|c|}{ Family Dicruridae } \\
\hline 5 & Black drongo & Dicrurus macrocercus & 11 & 8.73 & 2 & 1.73 & 0 & 0 & 10 & 4.23 & $\mathrm{LC}$ \\
\hline \multicolumn{12}{|c|}{ Family Sturinidae } \\
\hline 6 & Indian/Common myna & Acridotheres tristis & 4 & 3.17 & 4 & 3.47 & 2 & 1.62 & 4 & 1.69 & $\mathrm{LC}$ \\
\hline \multicolumn{12}{|c|}{ Family Pycnonotidae } \\
\hline 7 & White-cheeked bulbul & Pycnonotus leucogenys & 4 & 3.17 & 4 & 3.47 & 3 & 2.43 & 6 & 2.54 & $\mathrm{LC}$ \\
\hline 8 & Red-vented bulbul & Pycnonotus cafér & 1 & 0.79 & 7 & 6.08 & 6 & 4.87 & 2 & 0.84 & $\mathrm{LC}$ \\
\hline \multicolumn{12}{|c|}{ Family Nectariniidae } \\
\hline 9 & Purple sun bird & Cinnyris asiaticus & 5 & 3.96 & 3 & 2.60 & 6 & 4.87 & 3 & 1.27 & $\mathrm{LC}$ \\
\hline \multicolumn{12}{|c|}{ Family Motacillidae } \\
\hline 10 & White wagtail & Motacilla alba & 1 & 0.79 & 0 & 0 & 2 & 1.62 & 4 & 1.69 & $\mathrm{LC}$ \\
\hline 11 & Paddy field pipit & Anthus rufulus & 2 & 1.58 & 0 & 0 & 3 & 2.43 & 1 & 0.42 & $\mathrm{LC}$ \\
\hline \multicolumn{12}{|c|}{ Family Muscicapidae } \\
\hline 12 & Pied bush chat & Saxicola caprata & 0 & 0 & 7 & 6.08 & 1 & 0.81 & 2 & 0.84 & $\mathrm{LC}$ \\
\hline 13 & Collard bush chat & Saxicola torquata & 1 & 0.79 & 0 & 0 & 0 & 0 & 3 & 1.27 & $\mathrm{LC}$ \\
\hline 14 & Blue throat & Luscinia svecica & 0 & 0 & 1 & 0.86 & 0 & 0 & 2 & 0.84 & $\mathrm{LC}$ \\
\hline 15 & Blue capped redstart & Phoenicurus coeruleocephala & 0 & 0 & 0 & 0 & 2 & 1.62 & 3 & 1.27 & $\mathrm{LC}$ \\
\hline \multicolumn{12}{|c|}{ Family Sylviidae } \\
\hline 16 & Greenish warbler & Phylloscopus trochiloides & 2 & 1.58 & 2 & 1.73 & 3 & 2.43 & 1 & 0.42 & $\mathrm{LC}$ \\
\hline 17 & Lesser white throat & Sylvia curruca & 0 & 0 & 0 & 0 & 3 & 2.43 & 2 & 0.84 & $\mathrm{LC}$ \\
\hline 18 & Blyth's reed warbler & Acrocephalus dumetorum & 1 & 0.79 & 0 & 0 & 0 & 0 & 1 & 0.42 & $\mathrm{LC}$ \\
\hline 19 & Striated babbler & Turdoides earlei & 3 & 2.38 & 0 & 0 & 2 & 1.62 & 3 & 1.27 & LC \\
\hline \multicolumn{12}{|c|}{ Family Timaliidae } \\
\hline 20 & Jungle babbler & Turdoides striatus & 3 & 2.38 & 0 & 0 & 3 & 2.43 & 6 & 2.54 & $\mathrm{LC}$ \\
\hline 21 & Common babbler & Turdoides caudatus & 7 & 5.55 & 3 & 2.60 & 8 & 6.50 & 9 & 3.81 & $\mathrm{LC}$ \\
\hline 22 & Crested lark & Galerida cristata & 4 & 3.17 & 8 & 6.95 & 0 & 0 & 4 & 1.69 & $\mathrm{LC}$ \\
\hline \multicolumn{12}{|c|}{ Family Alaudidae } \\
\hline 23 & Oriental sky lark & Alauda gulgula & 2 & 1.58 & 1 & 0.86 & 0 & 0 & 4 & 1.69 & $\mathrm{LC}$ \\
\hline \multicolumn{12}{|c|}{ Family Passeridae } \\
\hline 24 & House sparrow & Passer domesticus & 6 & 4.76 & 2 & 1.73 & 7 & 5.69 & 7 & 2.96 & $\mathrm{LC}$ \\
\hline 25 & Sindh sparrow & Passer pyrrhonotus & 2 & 1.58 & 4 & 3.47 & 5 & 4.06 & 3 & 1.27 & $\mathrm{LC}$ \\
\hline 26 & Eurasian tree sparrow & Passer montanus & 5 & 3.96 & 3 & 2.60 & 3 & 2.43 & 4 & 1.69 & $\mathrm{LC}$ \\
\hline 27 & Yellow throated sparrow & Petronia xanthocollis & 1 & 0.79 & 2 & 1.73 & 0 & 0 & 1 & 0.42 & $\mathrm{LC}$ \\
\hline
\end{tabular}




\begin{tabular}{|c|c|c|c|c|c|c|c|c|c|c|c|}
\hline \multirow[t]{2}{*}{ S.No. } & \multirow[t]{2}{*}{ English / Local name } & \multirow[t]{2}{*}{ Scientific name } & \multicolumn{2}{|c|}{ Site-I } & \multicolumn{2}{|c|}{ Site-II } & \multicolumn{2}{|c|}{ Site-III } & \multicolumn{2}{|c|}{ Site-IV } & \multirow{2}{*}{$\begin{array}{l}\text { IUCN } \\
\text { status }\end{array}$} \\
\hline & & & $\mathbf{A}$ & RA & $\mathbf{A}$ & $\mathbf{R A}$ & $\mathbf{A}$ & RA & $\mathbf{A}$ & $\mathbf{R A}$ & \\
\hline \multicolumn{12}{|c|}{ Family Fringilidae } \\
\hline 28 & Common rose finch & Carpodacus erythrinus & 3 & 2.38 & 0 & 0 & 4 & 3.25 & 3 & 1.27 & $\mathrm{LC}$ \\
\hline \multicolumn{12}{|c|}{ Family Cisticolidae } \\
\hline 29 & Graceful prinia & Prinia gracilis & 2 & 1.58 & 2 & 1.73 & 4 & 3.25 & 2 & 0.84 & $\mathrm{LC}$ \\
\hline 30 & Plain prinia & Prinia inornata & 1 & 0.79 & 0 & 0 & 6 & 4.87 & 1 & 0.42 & $\mathrm{LC}$ \\
\hline \multicolumn{12}{|c|}{ Family Estrildidae } \\
\hline 31 & Indian silver bill & Lonchura malabarica & 4 & 3.17 & 5 & 4.34 & 1 & 0.81 & 6 & 2.54 & $\mathrm{LC}$ \\
\hline \multicolumn{12}{|c|}{ Family Oriolidae } \\
\hline 32 & Eurasian golden oriole & Oriolus oriolus & 0 & 0 & 0 & 0 & 0 & 0 & 0 & 0 & $\mathrm{LC}$ \\
\hline \multicolumn{12}{|c|}{ Family Prunellidae } \\
\hline 33 & Black throated accentor & Prunella atrogularis & 0 & 0 & 0 & 0 & 1 & 0.81 & 1 & 0.42 & $\mathrm{LC}$ \\
\hline \multicolumn{12}{|c|}{$\begin{array}{l}\text { Order Galliformes } \\
\text { Family Phasianidae }\end{array}$} \\
\hline 34 & Black francolin & Francolinus francolinus & 1 & 0.79 & 3 & 2.60 & 6 & 4.87 & 8 & 3.38 & $\mathrm{LC}$ \\
\hline 35 & Grey francolin & Franolinus pondicerianus & 0 & 0 & 1 & 0.86 & 1 & 0.81 & 7 & 2.96 & $\mathrm{LC}$ \\
\hline 36 & Chukar partridge & Alectoris chukar & 2 & 1.58 & 4 & 3.47 & 4 & 3.25 & 4 & 1.69 & $\mathrm{LC}$ \\
\hline 37 & See-See partridge & Ammoperdix griseogularis & 0 & 0 & 3 & 2.60 & 0 & 0 & 0 & 0 & $\mathrm{LC}$ \\
\hline \multicolumn{12}{|c|}{$\begin{array}{l}\text { Order Columbiformes } \\
\text { Family Columbidae }\end{array}$} \\
\hline 38 & Eurasian collared dove & Streptopelia decaocto & 5 & 3.96 & 8 & 6.95 & 6 & 4.87 & 5 & 2.11 & $\mathrm{LC}$ \\
\hline 39 & Laughing dove & Stigmatopilia senegalensis & 4 & 3.17 & 5 & 4.34 & 0 & 0 & 2 & 0.84 & $\mathrm{LC}$ \\
\hline \multicolumn{12}{|c|}{$\begin{array}{l}\text { Order Coraciiformes } \\
\text { Family Alcedinidae }\end{array}$} \\
\hline 40 & Common king kisher & Alcedo atthis & 0 & 0 & 2 & 1.73 & 2 & 1.62 & 1 & 0.42 & $\mathrm{LC}$ \\
\hline \multicolumn{12}{|c|}{ Family Coraciidae } \\
\hline 41 & European roller & Coracias garrulous & 0 & 0 & 2 & 1.73 & 0 & 0 & 0 & 0 & NT \\
\hline \multicolumn{12}{|c|}{ Family Meropidae } \\
\hline 42 & Small green bee eater & Merops orientalis & 0 & 0 & 0 & 0 & 2 & 1.62 & 0 & 0 & $\mathrm{LC}$ \\
\hline \multicolumn{12}{|c|}{ Order Falconiformes } \\
\hline \multicolumn{12}{|c|}{ Family. Accipitridae } \\
\hline 43 & White-rumped vulture & Gyps bengalensis & 0 & 0 & 3 & 2.60 & 3 & 2.43 & 0 & 0 & $\mathrm{CE}$ \\
\hline 44 & Shikra & Accipiter badius & 0 & 0 & 0 & 0 & 0 & 0 & 1 & 0.42 & $\mathrm{LC}$ \\
\hline 45 & Tawny eagle & Aquila rapax & 0 & 0 & 2 & 1.73 & 0 & 0 & 0 & 0 & $\mathrm{LC}$ \\
\hline 46 & Short-toed snake eagle & Circaetus gallicus & 1 & 0.79 & 0 & 0 & 1 & 0.81 & 1 & 0.42 & $\mathrm{LC}$ \\
\hline \multicolumn{12}{|c|}{ Family Falconidae } \\
\hline 47 & Common kestrel & Falco tinnunculus & 0 & 0 & 0 & 0 & 1 & 0.81 & 2 & 0.84 & $\mathrm{LC}$ \\
\hline $\begin{array}{r}\text { Order } \\
\text { Fan }\end{array}$ & $\begin{array}{l}\text { podiformes } \\
\text { y Apodidae }\end{array}$ & & & & & & & & & & \\
\hline 48 & House swift & Apus afffinis & 4 & 3.17 & 3 & 2.60 & 3 & 2.43 & 5 & 2.11 & $\mathrm{LC}$ \\
\hline $\begin{array}{r}\text { Order } \\
\text { Fan }\end{array}$ & $\begin{array}{l}\text { aprimulgiformes } \\
\text { y Caprimulgidae }\end{array}$ & & & & & & & & & & \\
\hline 49 & Sykes's nightjar & Caprimulgus mahrattenis & 6 & 4.76 & 1 & 0.86 & 1 & 0.81 & 5 & 2.11 & $\mathrm{LC}$ \\
\hline $\begin{array}{l}\text { Order } \\
\text { Fan }\end{array}$ & $\begin{array}{l}\text { haradriiformes } \\
\text { y Scolopacidae }\end{array}$ & & & & & & & & & & \\
\hline 50 & Common sand piper & Actitis hypoleucos & 0 & 0 & 2 & 1.73 & 1 & 0.81 & 2 & 0.84 & $\mathrm{LC}$ \\
\hline $\begin{array}{r}\text { Order } \\
\text { Fan }\end{array}$ & $\begin{array}{l}\text { coniiformes } \\
\text { y Ardeidae }\end{array}$ & & & & & & & & & & \\
\hline 51 & Litter egret & Egretta garzetta & 0 & 0 & 1 & 0.86 & 2 & 1.62 & 0 & 0 & $\mathrm{LC}$ \\
\hline Total & & & 126 & & 115 & & 123 & & 236 & & \\
\hline
\end{tabular}

*LC, Least concerned; *NT, Near threatened; *CE, Critically endangered. 


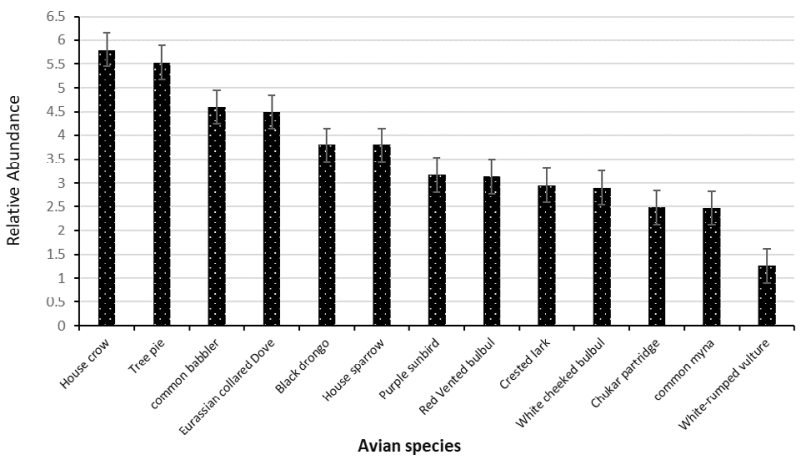

Fig. 3. Relative abundance (mean $\pm \mathrm{SE}$ ) of major avian species inhabiting Manglot Wildlife Park, Nowshera District, Khyber Pakhtunkhwa province.

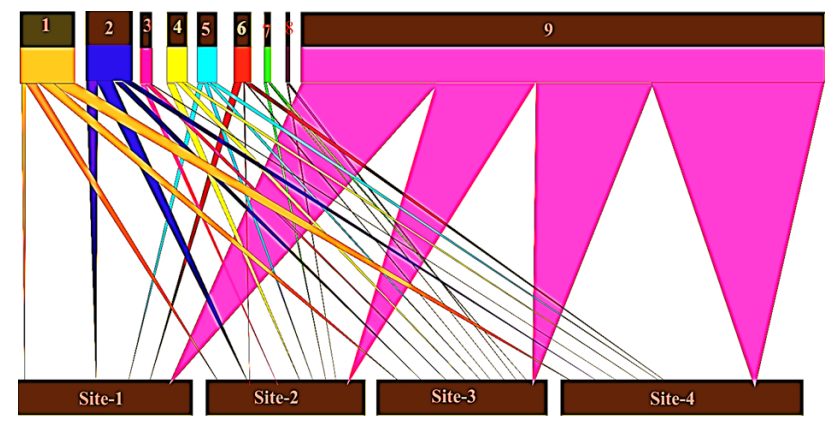

Fig. 4. Site web analysis of the comparative distribution of various bird orders at four different sampling sites at Manglot Wildlife Park, Nowshera

Sampling Sites: Site-I, Wildlife Range office; Site-II, Wildlife Rest House; Site-III, Karkareena Top; Site-IV, Compartment number 3.

Orders: 1, Galliformes; 2, Columbiformes; 3, Coraciiformes; 4, Falconiformes; 5, Apodiformes; 6, Caprimulgiformes; 7, Charadriiformes; 8, Ciconiiformes; 9, Passeriformes.

\section{Site-IV (Compartment number 3)}

At this sampling site, a total of 45 bird species were observed; the most abundant species was tree pie with relative abundance $(6.78 \%)$, followed by black drongo (4.24\%), common babbler (3.81\%), and house crow $(3.39 \%)$ (Table I).

\section{Relative abundance}

In terms of relative abundance in the study area, House crow showed the highest value $(5.8 \pm 0.32)$ among all avian species occurring in the park (Fig. 3), followed by tree pie, common babbler, Eurasian collared dove, black drongo, house sparrow and so on and the least by whiterumped vulture $(1.26 \pm 0.31)$.

Passeriformes was the most abundant order; its members were distributed at all four sampling sites (Fig. 4). Galliformes were also found distributed at all four sites, with more species occurring at sites III and IV. The Columbiformes were more distributed at sites II and I, with lesser number of species at sites-II and IV. Apodiformes were less abundant in the study area, although they occurred at all four sites. The order Caprimulgiformes was also less abundant but its species occurred more at sites-I and IV. Falconiformes were distributed at three out of four sites, with almost even distribution (Fig. 4).

\section{Population indices of avian species}

Species richness

Species richness at site I (Wildlife Range Office) was greater in winter than in summer, most probably because more seasonal birds visited this area as winter visitors from northern latitudes. Similar was the situation at the second (Wildlife Rest House) and fourth sampling sites (Compartment No.3). However, species richness showed no change at the third sampling site (Karkareena top) during winter and summer seasons (Fig. 2).

\section{Diversity index}

Diversity index of avifauna was low in summer than in winter at three out of four sampling sites (Fig. 2). However, at one sampling site (Wildlife Rest House), the avian diversity index was high in summer season too. Maximum Diversity Index (41.82) of avifauna was recorded at Site-II (Wildlife Rest House) in winter season, followed by site-I (13.67 at Wildlife office) in summer and 13.13 at Site-IV (Compartment No.3).

\section{Species evenness}

Avian Species Evenness was the highest (31.71) at Site-IV (Compartment No. 3) during winter season, followed by Site-III (27.81) also in winter, whereas the lowest value (2.18) of species evenness was recorded at sampling site $-\mathrm{I}$ (Wildlife office) during winter (Fig. 2).

\section{DISCUSSION}

Diversity is the key component of an ecosystem, and among species, birds have a significant place because they are noticeable and highly appreciated by humans. Birds, furthermore, play an informational role in charming public attention to natural habitats. The abundance and diversity of avian species, therefore, in pristine habitats could serve as a useful indicator of the natural status of that habitat. Ecologically, avifauna is of incredible importance as they are important pollinators and play an important role in seed dispersal. Indus flyway, for instance, provides foodstuff and residence for millions of migratory and resident birds 
(Omer and Saeed, 2006).

Pakistan harbours a wide range of ecosystems which, in turn, catch the attention of diverse birds to exploit their resources (Khan et al., 1996). More than 660 species of birds have been reported from the country and their occurrence in three zoo-geographical zones (Oriental, Palaearctic and Ethiopian) is unique in the world (Grimmett et al., 2001; Mirza and Wasiq, 2007). Only sporadic efforts have been made to collect baseline data, to evolve a conservation strategy, but the non-availability of reliable or consistent data hampers the formulation of policy and action plan for bird conservation. Pakistan has many climatic and ecological zones within a comparatively limited area (Roberts, 1991). Maximum number of birds move from central Asian countries and Europe towards wetlands of Pakistan to evade severe winter conditions. The birds enter into Pakistan flying over Karakorum, Suleiman and Hindu Kush ranges along the Indus River. Cranes, falcons, ducks, swans, flamingos, geese and waders are the main groups of migratory birds in the host country (Ali, 2005).

We developed a checklist of the avifauna occurring in the Manglot Wildlife Park and estimated their relative abundance. Most of bird species (31 species) recorded in the park belonged to the order Passeriformes. They inhabited the park most probably because of a diversity of tree species occurring here, which provide suitable habitat for these Passerines to live and breed. Common myna, house sparrow and house crow visit this site for drinking water and roosting on tree species found around the study area during both the seasons. Some species visited the site for utilization of different kinds of food at the study area like small fish, small insects, amphibians and small reptiles. Thus, occurrence of 31 species of this order gives a diversity of the fauna to the park.

Similarly, Faiz et al. (2015) reported for Toli Pir National Park, Azad Jammu and Kashmir, a total numbers of 202 birds species, belonging to 55 families, including two vulnerable (Tragopan melanocephalus, Catreus wallichii), two endangered; Peregrine falcon and the Saker falcon (Falco peregrines and Falco cherrug milvipes). In the current study, we also recorded bird species belonging to order Falconiformes, family Falconidae: common kestrel (LC) was recorded. Critically endangered whiterumped vulture (Accipitridae), which is surviving at only a few places in the country. The occurrence of this vulture species in Manglot Wildlife Park is encouraging and a healthy sign for the study area. However, the population of this vulture needs to be monitored regularly for conservation purposes. Shikra, eagle and common kestrel are also very important raptor species occurring in the park that play a vital role in the food chain.
The species richness and diversity indices computed were found high in winter season compared to summer, which is logical because in winter season, many migratory bird species join the avifauna in Manglot Wildlife Park. However, these migratory species leave the area before the start of summer, therefore, summer indices were found low. Earlier published literature shows that it is not easy to find habitat for the bird species as it provides necessities such as food, shelter and water, and each species survives in a specific environment (White and Garrot, 1990). Every species selects sites which are the most suitable for it and mostly selected high potential areas that support the species rather than areas having low potential (Manly et al., 2002). Manglot Wildlife Park therefore provides suitable habitat for 51 different bird species occurring here.

\section{CONCLUSION}

The avifauna of Manglot Wildlife Park comprises of 51 species belonging to 10 orders and 27 families. Major orders included Passeriformes, Galliformes, Falconiformes, and Columbiformes. The relative abundance of different bird species in descending order is: house crow, tree pie, common babbler, Eurasian collared dove, black drongo, house sparrow and others. The significant finding of the current study is the occurrence of white-rumped vulture which is critically endangered and is surviving only at a few places in the country. The diversity index and species richness were higher in winter season as compared to summer.

Statement of conflict of interest

The authors have declared no conflict of interest.

\section{REFERENCES}

Ali, S., Ripley, S.D. and Dick, J.H., 1987. Compact handbook of the birds of India and Pakistan: together with those of Bangladesh, Nepal, Bhutan and Sri Lanka. Oxford University Press, New Delhi, India.

Ali, Z., 2005. Ecology, distribution and conservation of migratory birds at Uchalli Wetlands Complex, Punjab, Pakistan. PhD thesis. University of the Punjab, Lahore, Pakistan.

Ali, Z., 2006. Avian species analysis at three major wetlands complex Pakistan. Biologia (Pakistan), 2: 203-213.

Bibby, C.J., Burgess, N.D., Hill, D.A. and Mustoe, S.H., 2000. Bird census techniques. $2^{\text {nd }}$ edition. Academic Press, London.

Faiz, A-U-H., Abbass, F., Ali, Z. and Zahra, L., 2015. 
Avifaunal diversity of Tolipir National Park Azad Jammu and Kashmir Pakistan. J. Anim. Plant Sci., 25: $404-409$.

Grimmett, R., Inskipp, C. and Inskipp, T., 2001. Pocket guide to the birds of the Indian subcontinent. Oxford University Press.

Grimmett, R., Roberts, T. and Inskipp, I., 2008. Birds of Pakistan. Christopher Helm, London, pp. 258.

Khan, A.A., Khan, R., Ullah, A., Ali, M., Mahmood, J.A. and Sheikh, K.M., 1996. Conservation perspectives of the imperial Aquila heliacal and steppe eagle Aquila nipalensis in Pakistan. Eagle Studies World Walking Group on Birds of Prey (WWGBP) Berlin, London and Paris.

Klein, A.M., Vaissiere, B.E., Cane, J.H., SteffanDewenter, I., Cunningham, S.A., Kremen, C. and Tscharntke, T., 2007. Importance of pollinators in changing landscapes for world crops. Proceed. Roy. Soc. London B: Biol. Sci., 274: 303-313.

Manly, B.F.J., McDonald, L., Thomas, D.L., McDonald, T.L. and Erickson, W.P., 2002. Resource selection by animals: Statistical design and analysis for field studies. Kluwer Academic Publishers. ISBN: 1402006772

Mirza, Z.B. and Wasiq, H., 2007. A field guide to birds of Pakistan. Published by WWF-Pakistan, Bookland Lahore. pp. 366.

Omer, S. and Saeed, A., 2006. Environmental baseline survey and monitoring of Taunsa Barrage Emergency Rehabilitation and Moderinization
Project: Socioeconomic Study. WWF, Pakistan. pp. 57.

Pathan, A.J., Khan, S., Akhtar, N. and Saeed, K., 2014. Diversity and distribution of avian fauna of Swat, Khyber Pakhtunkhwa, Pakistan. Adv. Zool., Article ID 430297, pages 7. https://doi. org/10.1155/2014/430297

Roberts, T.J., 1991. The birds of Pakistan, Vol I: Regional studies and non-Passeriformes. Oxford University Press, U.K.

Schrag, A.M., Zaccagnini, M.E., Calamari, N. and Canavelli, S., 2009. Climate and land-use influences on avifauna in central Argentina: Broad-scale patterns and implications of agricultural conversion for biodiversity. Agric. Ecosys. Environ., 132: 135142. https://doi.org/10.1016/j.agee.2009.03.009

Shah, S.A., 2011. Conservation of endangered species in Khyber Pakhtunkhwa. J. Anim. Pl. Sci., 21: 400-404.

The Khyber Pakhtunkhwa Wildlife Department. 2015. The Khyber Pakhtunkhwa Wildlife Biodiversity (Protection, Preservation, Conservation and Management) Act. Passed on $5^{\text {th }}$ January 2015, forced on $9^{\text {th }}$ January 2015.

Whelan, C.J., Wenny, D.G. and Marquis, R.J., 2008. Ecosystem services provided by birds. Annls N.Y. Acad. Sci., 1134: 25-60. https://doi.org/10.1196/ annals. 1439.003

White, G.C. and Garrott, R.A., 1990. Analysis of wildlife radio tracking data. Harcourt Brace Jovanovich, New York. 